\title{
Innovation for health promotion: products to help treating child cancer
}

\author{
Catherine Ribeiro Rosa, Ana Elise da Silva Gonçalves, Fabiane Vieira Romano, Amara Lúcia Holanda Tavares Battistel \\ Universidade Federal de Santa Maria \\ e-mails: catherine.r.rosa@gmail.com; anaelise_sg@hotmail.com; fabiromano@gmail.com; amarahb@gmail.com
}

\begin{abstract}
Based on the designer's need to act in the social context, this work was conducted in the Hospital Universitário de Santa Maria (HUSM), with the main goal of providing entertainment and fun to children and young patients who underwent treatments or were admitted in the Chemotherapy Ambulatory and in the Centro de Tratamento da Criança e Adolescente com Câncer - Treatment Center for Children and Teenagers with Cancer (CTCriaC). Possibilities were explored so that the designer could act as an intermediary between patients treated there and their hospital daily life, in order to collaborate and provide them with a more pleasant stay during chemotherapy treatments and hospitalization. Paying visits, observing the routine of patients and other involved individuals, as well as researching about illnesses and their treatments, interviewing the medical staff and the investigations conducted by graders from the Occupational Therapy course of the Universidade Federal de Santa Maria (UFSM) about the needs and desires expressed by children and teenagers, allowed identifying intervention opportunities for the designer to improve the environment. As a result, we had the development of two products that explore activities, mixing in a productive way with the hospital routine to which patients are submitted.
\end{abstract}

Keywords: child oncology, social design, leisure design, design in the hospital environment.

\section{Introduction}

It is widely known that childhood is the most important phase for the development of human beings, which will prepare individuals to take care of themselves in the adult life. In this context, the role of playing is fundamental and crucial; it helps facing the adversities to which children may be exposed during their life, such as parents' separation, city or school changes, learning difficulties or even fragile health conditions.

Sometimes, during an illness, it is necessary to reorganize everyday life, trying to adapt to treatment needs. This interference may be even bigger if the hospital routine needs to be included in the life of the sick person, both for prolonged treatments in the hospital and hospitalization, since it is necessary to get used to an unknown world, with situations, relationships, routines and activities that are different from the usual ones.

During childhood, an episode of illness may turn into trauma, as well as into a delay or even an interruption in the process of growth and development (BORTOLOTE; BRÊTAS, 2008, p.423).

And, in case of an illness like cancer, which is considered a diagnose with high social impact exactly for being the cause with the highest youth mortality for illness index in Brazil (INSTITUTO DESIDERATA, 2013), the need to consider emotional factors is crucial.
In Brazil, it is estimated that 12 to 13 thousand children are diagnosed with cancer every year (GUIA..., 2013), and cancer treatments specifically may be prolonged "[...] exposing children to invasive and unpleasant procedures, both physical and emotional" (MOTTA; ENUMO, 2004, p. 194).

The existence of an environment promoting the well-being of patients may collaborate, not only with comfort, but also turning into a factor for the success of the treatment by providing the opportunity to keep on developing in a positive way.

"The environment shall encourage health and shall be organized in such a way to better attend patients' needs" (BEGNIS; CARVALHO, 2006, p. 111). The negative aspects of treatments may be reduced through solutions that contribute to transform the space where they stay into an ally for the cure. Moreover, children needs with cancer do not only refer to medical treatments. Even in the hospital environment, playing, learning and interacting are still important activities for their development, and the place where they are must provide means to grow up in the best way.

For hospitalized patients specifically, it is important to provide the necessary conditions to stay connected to the world and their daily life, even in a more limited way. Thus, the need for entertainment or resources to express the 
feelings developed by illnesses becomes evident. Therefore, playing and toys are vital in helping hospital treatments of this illness.

With the presence of toys and recreational elements, "[...] treatment environments may be related to leisure, and no longer be seen only as places of procedures generating suffering" (GOMES; COLLET; REIS, 2011, p. 586).

Not only medicine has the possibility of working to take care of these patients, but also the different professions may act within their competences to help children perception during an illness experience. Sometimes, even simple solutions may contribute, so why not including design in this task?

In order to attend this need, designers may and must act as an intermediary, since they have innumerous abilities to contribute soothing the difficulties and the pain of people submitted to any type of health treatment, in this case acting on the social bias of the profession.

Pazmino (2007, p.3) highlights the way in which design is involved with social causes, which need more attention:

Design for society consists in developing products that attend real specific needs of socially, culturally and economically less privileged people, as well as people with low incomes or special needs due to age, health or disabilities.

Moreover, the contact with the designer's creations is intrinsic to our daily life. Objects are intermediaries of our actions and innumerous decisions that we take on a daily basis are related to them; they are also responsible to promote social relations, experiences and behaviors. According to Menezes (2008, p.28),

[...] we cannot build "products with emotions or feelings", but "imagine and plan" situations that will trigger positive feelings. Imagining and designing products to promote and benefit users' personal and social relations and promote social actions aiming at common good.

Margolin (2007, p. 4) adds: "[...] designers are certainly among those whose positive contributions are essential to build a more human world". Through this activity, we present different possibilities to explore users' needs and their response to the available products and services; it is possible to act for the benefit of people with projects that improve the interaction of individuals with the space and situations that surround them, interfering in human psychology in order to help everyone's experiences.

With the aim of providing positive experiences, this work was developed in the Chemotherapy Ambulatory and the Centro de Tratamento da Criança e Adolescente com Câncer - Treatment Center for Children and Teenagers with Cancer (CTCriaC) of the Hospital Universitário de Santa Maria (HUSM), located in the campus of the Universidade Federal de Santa Maria (UFSM), in partnership with the
Occupational Therapy Course. Based on the case study of the mentioned environments, the project has the goal to introduce design in the hospital environment by developing products that, simultaneously, provide entertainment and fun and are proper to be used by children and young patients that experience treatments or hospitalization.

\section{Design and environment}

There are many definitions about the profession of the designer and it is possible to notice that most of them are characterized by focusing on the human being, the individual that will be benefited by the creation. Some authors place with more relevance the question of man as the center of the process and defend the fact that this is what gives real sense to design. Redig's adapted definition (1977/2005), described by Gomes and Medeiros in the book Ideias, Ideais e Ideações: para design/desenho industrial (Ideas, Ideals and Ideations: for design/industrial design), proposes a reflection about the subject:

Industrial Design/Design is the simultaneous equating of anthropological (observe the "behavior" and "ideas" of the client/consumer/user), ecological (watch out for the life cycle of the designed product, "preserve" and "protect"), economic (notice that "cost" is a parameter, but what is important is "value"); ergonomic (respect human nature - the "adequacy" and make life "easier and comfortable"), philosophical (think that your "esthetic" is the industrial one and your "ethics" is professional), geometrical (qualify to simplify - "synthesis" - and dominate - "coherence" - lines), marketing (compare the quality of a product with your "price" \& "promotion"), psychological (develop necessarily your "perception" and "creativity"), technological (study how to obtain "materials" and "manufacture") factors in the design of elements and structures that are destined to common good and/or to human culture" (GOMES; MEDEIROS, 2010, p.16).

Design playing fields are innumerous, but practices aiming at improving life quality have grown stronger and an example of this important proposal is the designer intervention in the hospital environment. Making these spaces more welcoming and comfortable for patients may intensify the benefits performed there. In case of children patients, who are in a process of physical and psychological formation and need special care, playing at the hospital stimulates experience and perception exchange with children sharing the same situation, facing the therapeutic conditions necessary to be cured.

As well as cancer treatment, the attention given to social aspects of the disease is also important, since sick children and teenagers shall receive full attention, within their familiar context. Cures shall not only be based on biological recovery, but also on the well-being and life quality of patients. In this sense, since the beginning of 
the treatment, psychosocial support shall be given to them and their families; this involves the commitment of a multi-professional team and the relation with different sectors of society, involved in supporting families and children and teenagers health (INSTITUTO NACIONAL DO CÂNCER, 2013).

\subsection{HUSM Chemotherapy Ambulatory}

In the HUSM Chemotherapy Ambulatory, space is divided into two environments. Figure 1 approximately demonstrates the arrangement of furniture and tools necessary to apply ambulatory chemotherapy treatments. In the figure, the lower ellipse demonstrates a small division of approximately $1.60 \mathrm{~m}$ height, whereas the upper ellipse presents a division that follows the total height of the room.

Between the two spaces there are armchairs for patients during chemotherapy, basins and instruments for the treatment, pieces of furniture to organize the necessary documents for the place functioning and service, and little desks for paperwork.

According to the approximate floor plan it is possible to observe that there is little space to circulate and accommodate patients, also considering the presence of the medical staff and, sometimes, of occupational therapists and psychologists.

When patients are accompanied, as children are, space is even more reduced.

There, both adult/senior patients and children/teenagers are treated. Chemotherapy sessions last according to treatment types and needs; they can last up to seven hours per day.
With the information obtained through questionnaires and on site observations performed with the help of graders from the UFSM Occupational Therapy course, it was possible to check the needs and possibilities of working on the environment. Among them, it was observed that there is no available space for recreational intervention exclusive to young patients, since they share the space with adults; ideally, a product that may be moved should be developed.

Children's preference for specific toys and hobbies was also investigated. Considering the limited movement they have, they showed preferences for games (jigsaw puzzles, memory, domino, word games), videogames, drawing and painting, watching videos and listening to music.

During the observations performed at the HUSM Chemotherapy Ambulatory, an unusual situation showed a funny way to go around the hospital: while the child under treatment climbed up the serum/medicine support, the mother made it move, as if she was taking her child for a walk. This attitude directed a project for the creation of a carrier for the child and the serum/medicine needed for the treatment that may be used inside the hospital, trying to accomplish hygiene and safety standards.

\subsection{CTCriaC}

CTCriaC is a hospitalization unit for children and young adults ( 0 to 20 years old) with leukemia, solid tumors and hematological diseases, which gives support in diagnosing, treating and maintaining, with the help of nurses, doctors, psychologists, nutritionists, physiotherapists and occupational therapists, helping more than 450 patients every year. Its physical structure follows hospital standards,

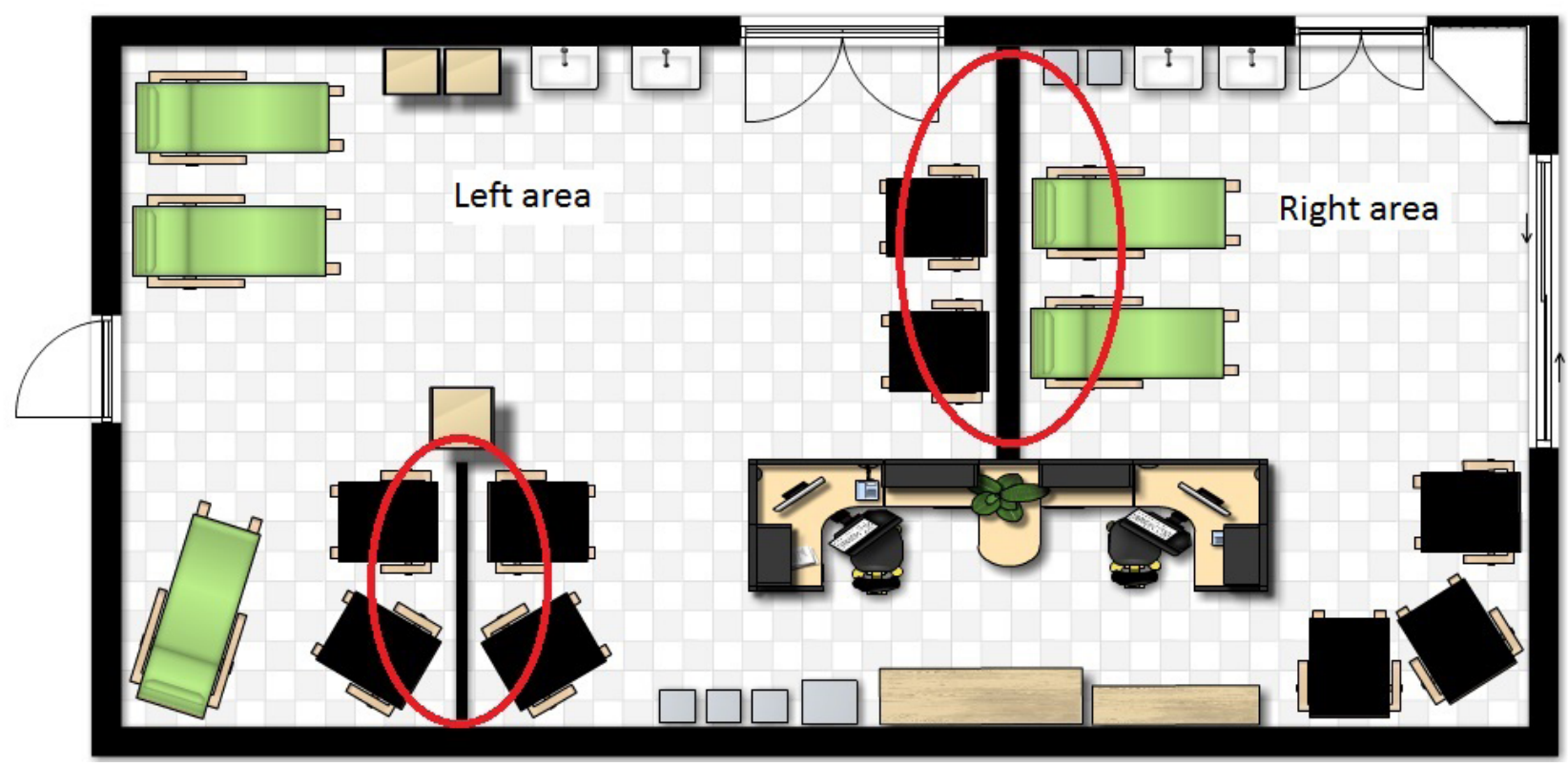

Figure 1. HUSM Chemotherapy Ambulatory approximate floor plan. Source: Gonçalves (2014). 
also counting on a toy library to help humanizing the place; it provides patients with a leisure environment.

However, the rooms where they are hospitalized (Figures 2, 3), do not present any welcoming feature or characteristic that could make them feel relaxed and comfortable, since the toy library is not available full time because it needs the supervision of healthcare professionals or volunteers.

Currently, this environment has few recreational resources and its furniture has a quite restricted use, due to medical and procedure routines performed by healthcare professionals.

Observing on site resources, it was possible to identify the lack of products that may be used both recreationally and as a support. Since these patients' stay is usually longer than just one day, and sometimes, depending on patients' conditions, they are not allowed to leave the room, all their activities are developed in this place. A recreational support that also allows studying, placing books, notebooks or even eating, would provide children with a more comfortable stay.

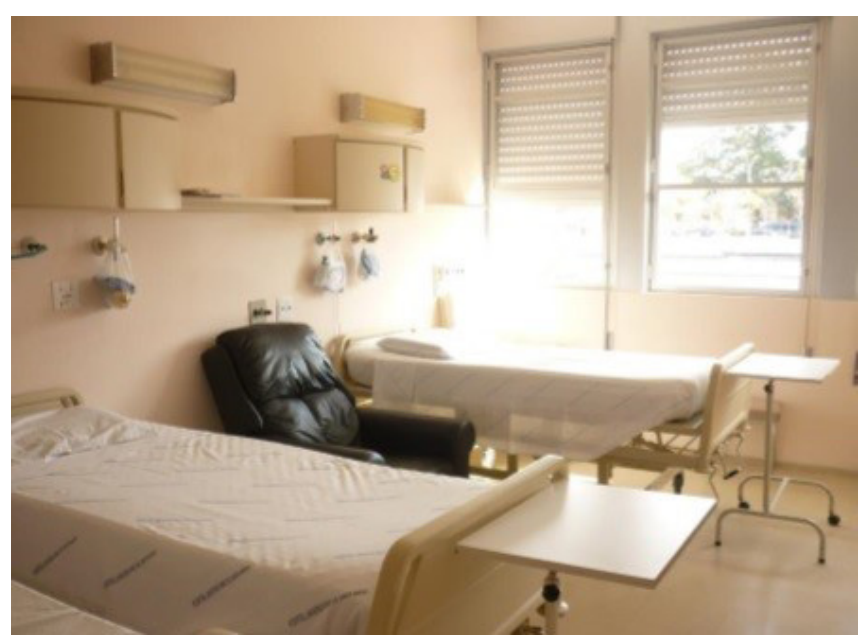

Figure 2. Pictures of CTCriaC rooms. Source: Rosa (2013).

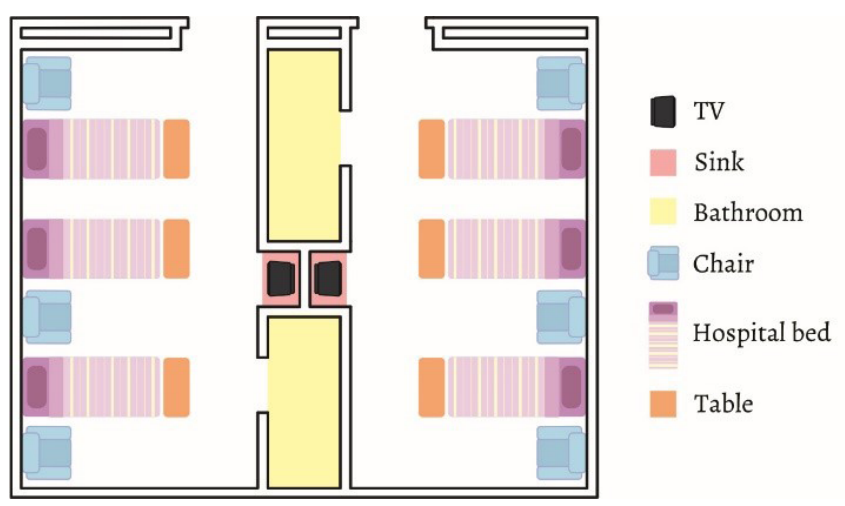

Figure 3. CTCriaC rooms approximate floor plant. Source: Rosa (2013).
Then, it was possible to identify the need for designing a multiple activity support that may fit the hospital medium to attend hospitalized patients. The product must have the goal of providing patients with hobbies and different manners of use, performing its function without interfering in the hospital routine and adapting to the environment; it must respect local activities and also be acceptable in this medium.

\section{Results}

With the goal of creating satisfactory results to the development of the products so far defined as carrier and multiple activity support, different methodological processes were used, according to the needs presented by each project.

\subsection{Carrier to help child oncologic treatment}

To accomplish the project, methodological concepts from four authors were gathered: Bonsiepe (1984), Brod and Romano (2013), Baxter (1998) and Löbach (2001), according to the needs of the project steps proposed by them (Figure 4).

The information phase of the project involves, according to its name, gathering information needed for project orientation. It is the theoretical background and researches/registers performed in the studied environment, different analyses about the situation and existing products and the definition of the project requirements that will guide its configuration.

The second phase of the project, the conceptual project, includes procedures to create alternatives and the creation itself of alternatives proposed for the project, as well as the development of tridimensional models, in case of need.

During the third phase, the preliminary project, there are the evaluation and definition of the best alternative, as well as the creation of the product.

In the detailed project phase, work is concluded with technical design, functional model presentation and final analysis of the product.

According to the Specific Methodology for Project Education and Industrial Design Teaching, the project information phase (or preparation) "[...] allows creating and organizing Project and Linguistic Analytical Techniques, proper to burst the vocabulary and project fluency of designers" (BROD; ROMANO, 2013, p. 12); thus, all technical and serum/medicine support, infant carrier and baby walker usage information were collected, in order to analyze the aesthetics and functioning of these products.

In this phase, we also studied safety requirements permeating the manufacturing of products for children. Instituto Nacional de Metrologia, Qualidade e Tecnologia (2013) highlights toy conformity assessment performed through the Inmetro Ordinance n. 177, in Brazil since 
1988, in order to preserve the physical and health integrity of children.

Toys must not have spikes or cutting edges and small parts that may detach easily and cause accidents. Moreover, they cannot be manufactured or painted with toxic materials, since children usually disassemble them and put them in their mouth, nose and ears, increasing chances of asphyxia, inhalation and oral intoxication, which may turn toys into real traps if they are not well designed for the age range they are meant for (INSTITUTO NACIONAL DE METROLOGIA..., 2013, p. 1).

In addition to these considerations, it is important to observe toy hygiene, in order to avoid infection or contamination risks. Due to the nature of this work, exceptionally, health conditions of users and the environment where the product will be used, the hospital environment, shall be considered. This condition needs specific requirements of materials presenting the possibility of an effective cleaning, with smooth and easy to access surfaces.

Starting from these studies, project requirements were defined; they were organized in a table (Figure 5) and divided into esthetic, which refer to the shape and appearance of the product, functional, which determine its functioning and technical, which determine manufacturing. They were also classified as mandatory and desirable.

The concept project phase started, where alternatives are created through designs and prototypes in alternative materials. Subsequently, the alternative most attending needs and requirements is selected, starting the preliminary project phase. Once the best alternative is defined (highlighted in Figure 6), the functional model is created.
We decided to work with stainless steel tubes in the carrier main structure, since this material is resistant to certain loads and to time action, as well as allowing easy cleaning. For the other components, we used polyethylene polymer (PE), which varies from low impact resistance to almost unbreakable, depending on the type, as well as having almost no humidity absorption, easy molding and pigmentation, low cost and no toxicity (LESKO, 2012).

Various tests were conducted with children, so that the main structure of the carrier presented a configuration according to the anthropometric proportion of possible users. In Figure 7 it is possible to observe the changes performed, such as inclination and base reduction for the activity clipboard, the curve increase in the back part of the structure to help stability and the reduction of the seat structure.

The detailed project phase resulted, then, in the functional model: the configuration of a carrier with serum/medicine support and activity clipboard (Figure 8) so that children may experience some entertainment in the hospital environment while they are submitted to chemotherapy treatments.

Since one of this project's goals is to promote the emotional relationship of the user with the product, during the process we defined a theme, so that its characteristics could stimulate even more its involvement with the user. Then, the circus theme was chosen, in order to give the object the magical atmosphere and emotionally exciting concept of circus, starting from the conscience that the show has the goal to create pleasant and happy memories.

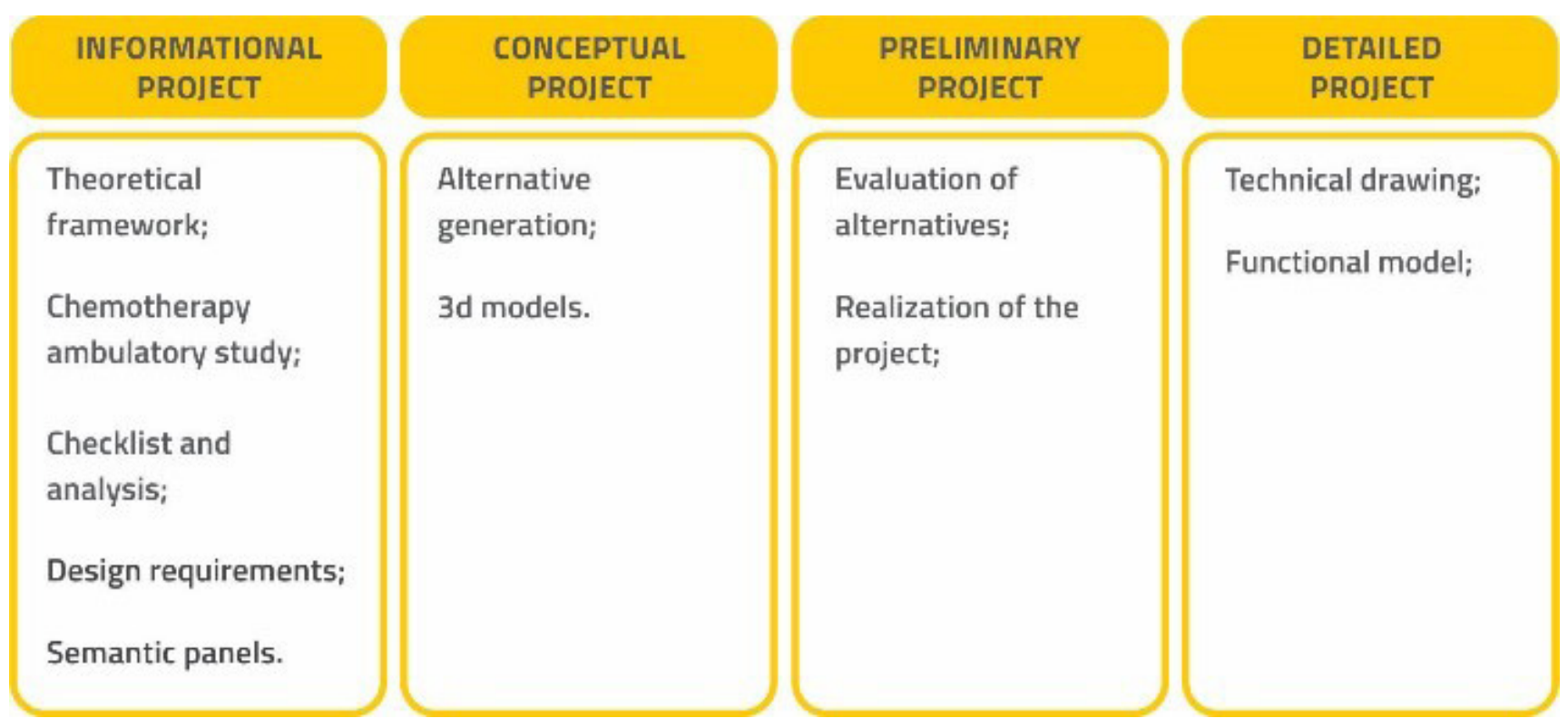

Figure 4. Project methodology. Source: Gonçalves (2014). 


\begin{tabular}{|c|c|c|c|}
\hline & \multirow{2}{*}{\multicolumn{2}{|c|}{ REQUIRED }} & \multirow{2}{*}{ DESIRABLE } \\
\hline & & & \\
\hline 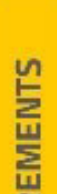 & Simple and fluid & & $\begin{array}{l}\text { Because of the necessity of not } \\
\text { having sharp edges, it is } \\
\text { possible to exploit the organic } \\
\text { forms that exhibit fluidity and }\end{array}$ \\
\hline $\begin{array}{l}\text { 뭄 } \\
\text { 븐 }\end{array}$ & Colorful & & $\begin{array}{l}\text { Although the colorful awaken } \\
\text { the attraction of the child, there } \\
\text { are other forms of stimulus. }\end{array}$ \\
\hline 嵌 & Smooth surface & $\begin{array}{l}\text { It is essential that the surface is } \\
\text { easy to be cleaned. }\end{array}$ & \\
\hline & Practicality & $\begin{array}{l}\text { The product should present } \\
\text { simplicity and be intuitive so it } \\
\text { can be easily used. }\end{array}$ & \\
\hline 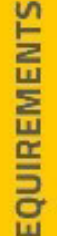 & Multifunctionality & $\begin{array}{l}\text { Beyond the cart function, must } \\
\text { support the continuation of } \\
\text { chemotherapy. }\end{array}$ & $\begin{array}{l}\text { The ideal is that the cart, in } \\
\text { addition to its primary function, } \\
\text { allow children to develop other } \\
\text { activities such as games and } \\
\text { hobbies. }\end{array}$ \\
\hline $\begin{array}{l}\text { 돌 } \\
\text { 은 } \\
\text { 늘 }\end{array}$ & Security & $\begin{array}{l}\text { It is essential that the product } \\
\text { offers the user security, } \\
\text { especially regarding children. }\end{array}$ & \\
\hline & Ergonomics & $\begin{array}{l}\text { Ergonomic aspects should be } \\
\text { considered for the user to } \\
\text { remain comfortable for a } \\
\text { reasonable time. }\end{array}$ & \\
\hline 는 & Suitable material & $\begin{array}{l}\text { The material must be suitable } \\
\text { for the cleaning efficiency. }\end{array}$ & \\
\hline 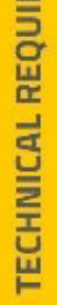 & Low cost & & $\begin{array}{l}\text { The economic viability is } \\
\text { important for the product } \\
\text { considering its social value. } \\
\text { However, the materials for } \\
\text { their manufacture may be } \\
\text { expensive due to the need for } \\
\text { cleaning and resistance. }\end{array}$ \\
\hline
\end{tabular}

Figure 5. Project Requirements. Source: Gonçalves (2014). 


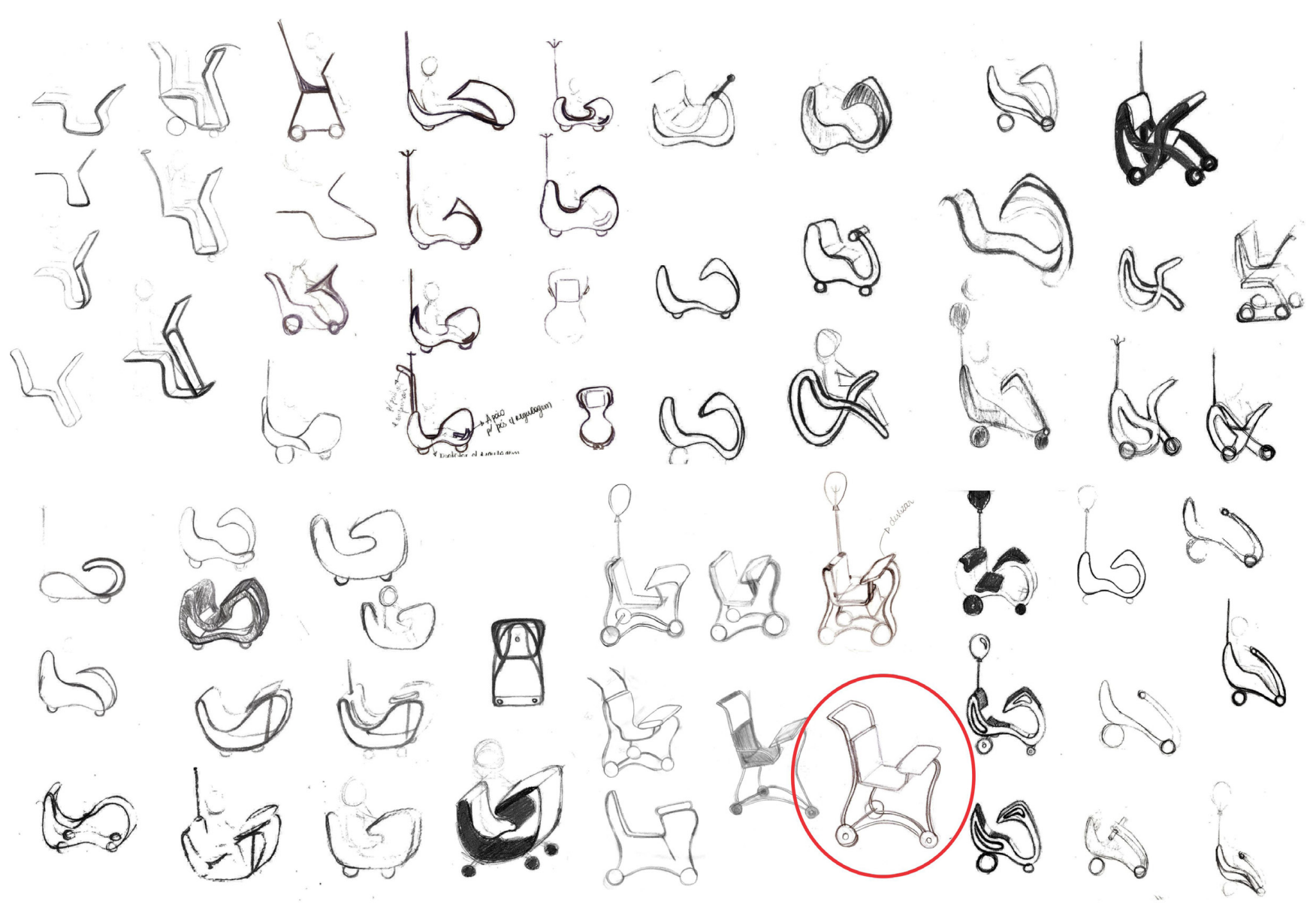

Figure 6. Alternative creation. Source: Gonçalves (2014).

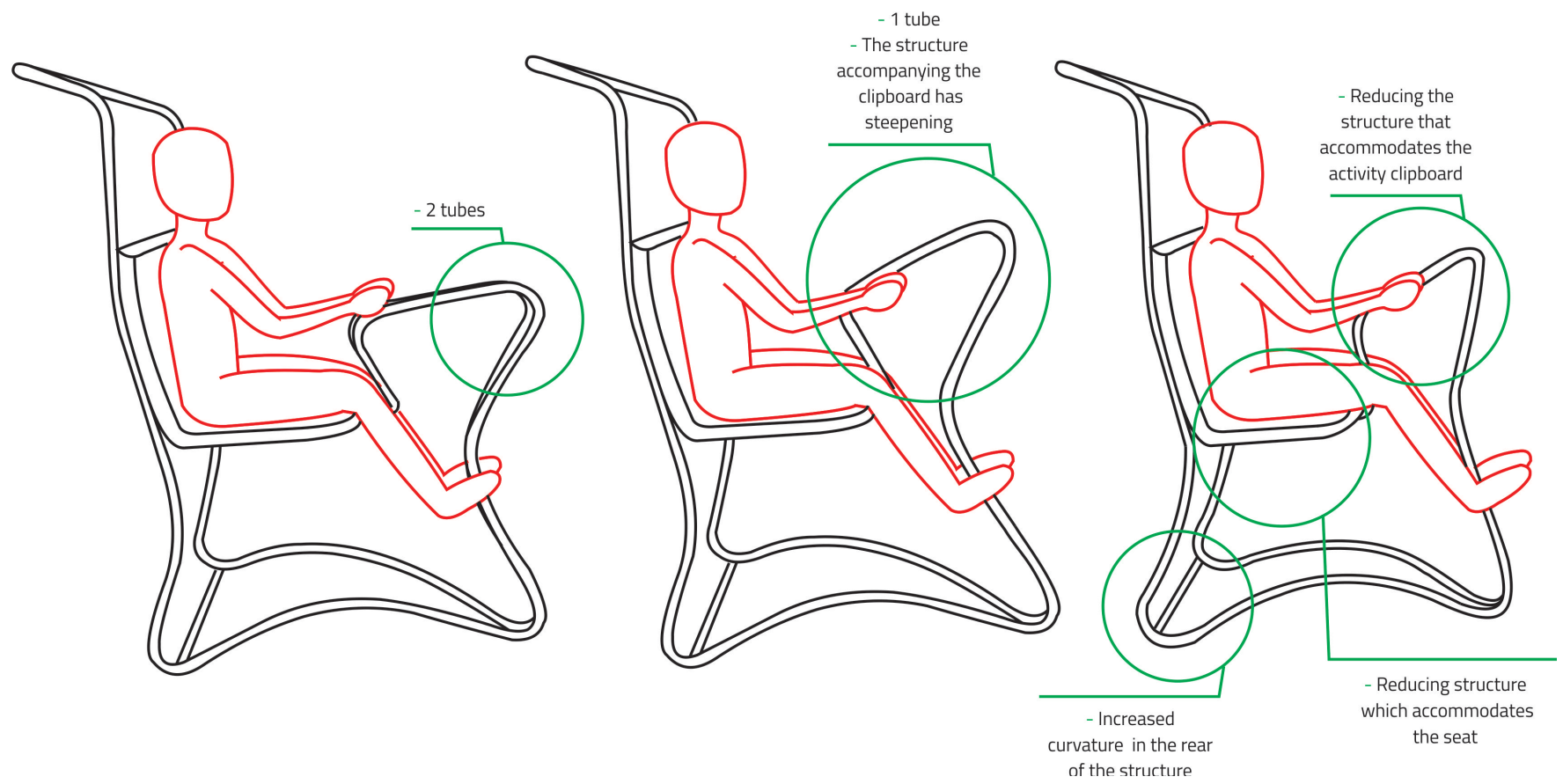

Figure 7. Layout to understand changes in the main structure of the carrier. Source: Gonçalves (2014). 
After finishing, the carrier model was taken to the HUSM Chemotherapy Ambulatory in order to be evaluated, both by professionals who work there and by parents and children patients, who will be the product users (Figures 9, 10).

Responses to the product were quite positive, both by users (oncologic patients aged between 4 and 10),
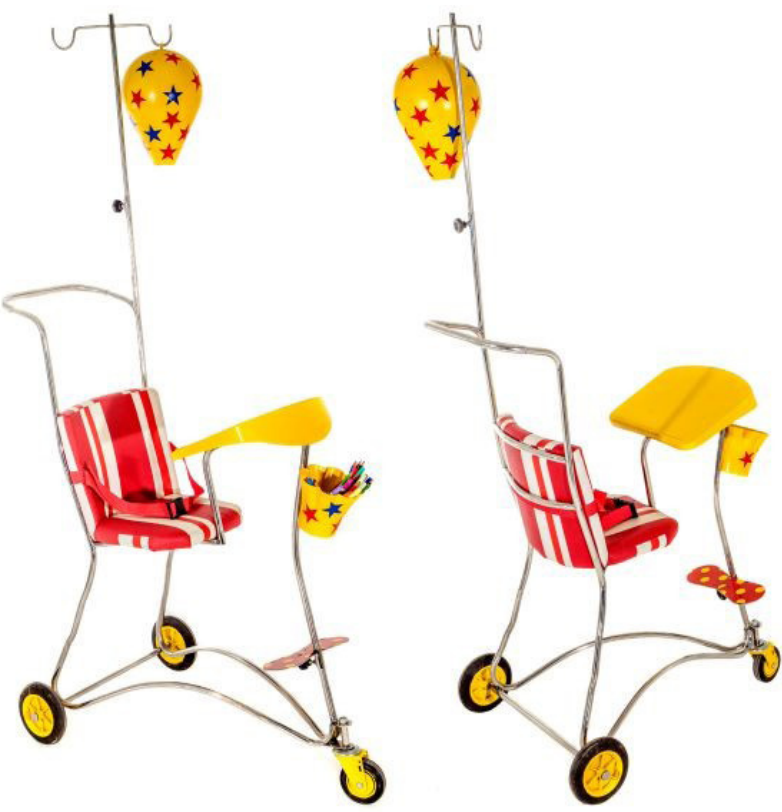

Figure 8. Recreational carrier to help child oncologic treatment. Source: Gonçalves (2014). and by parents and professionals working in the hospital environment.

The product appeared to be totally proper to attend the body proportions of different age ranges, due to the possibility of regulating the feet support and the serum/medicine support, allowing a greater number of children to benefit from the recreational intervention in the treatment place.

\subsection{Multiple activity desks}

To develop the multiple activity desk, the used method was based on Bonsiepe (1984) and also on the methodology developed by Projetar Empresa Júnior de Desenho Industrial (MATTE et al., 2013), for being cyclic and flexible, attending every project in its peculiarities. Combining and adapting these two methods, we arrived at the project process that involves four great phases: problem, comprehension, configuration and supervision (Figure 11). Each phase is divided into steps, activities and tools; the steps are the phase direction, the activities are the description of what shall be made and the tools tell how it shall be made.

Work problem includes the first topics of this article, where researches about environment, public, illnesses and all the implications of the context were performed. Through this, it was possible to start the following phases of project configuration, which involve concept, conception and codification of the product.

With the 3 questions by Gui Bonsiepe (1984) - What? Why? And how? - the problem to be solved is defined as:
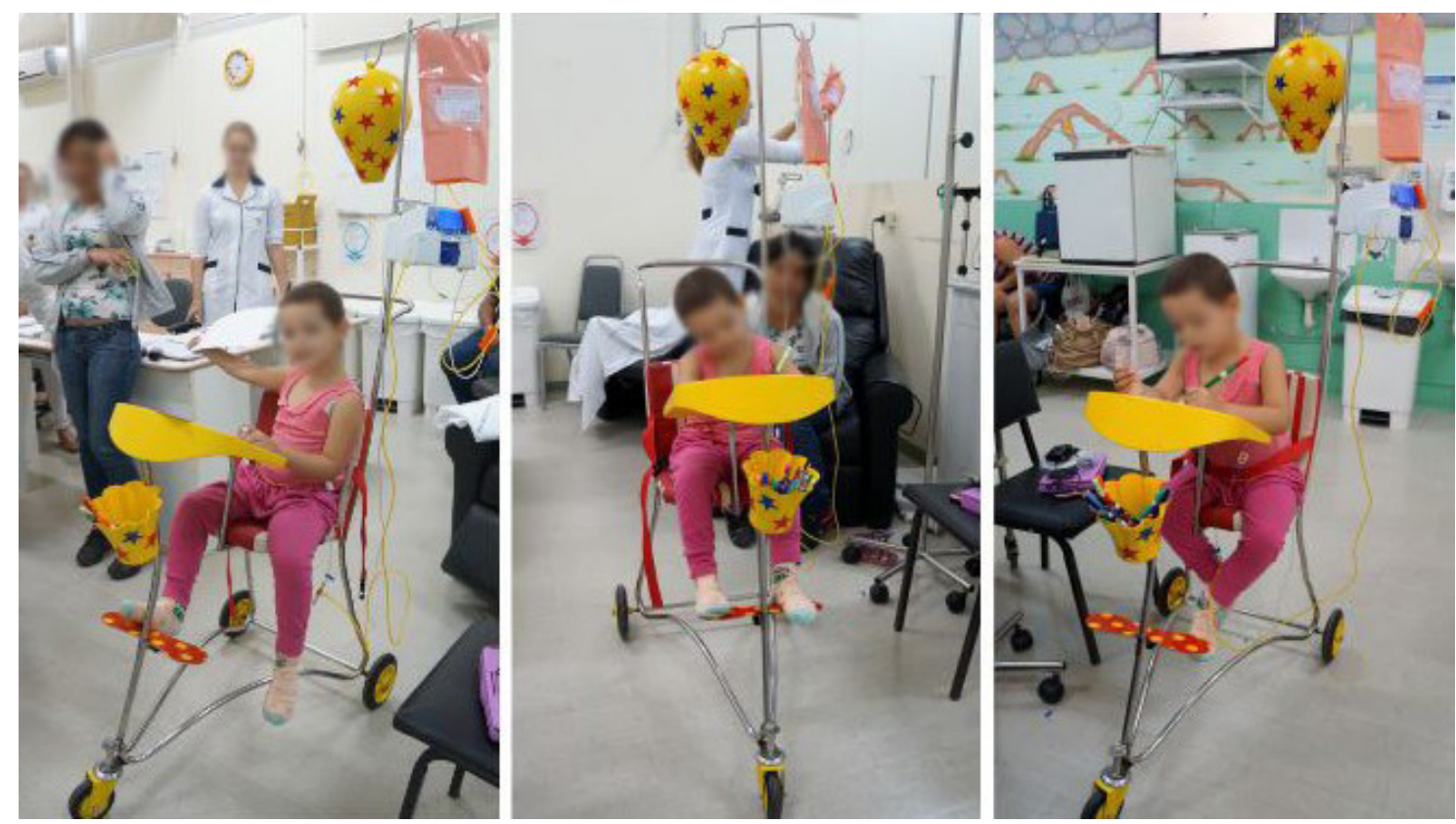

Figure 9. Carrier usage by HUSM Chemotherapy Ambulatory patients.

Source: Gonçalves (2014). 
designing a multiple activity support that may fit the hospital medium to attend hospitalized patients.

Considering that the product does not have a specific category and that it must allow multiple uses, the researches and analyses conducted during the comprehension phase focused on the functions that it should perform, classified into three main ones: playing, storing and giving support.

During this phase, similar products to the product to be developed that would perform similar activities were also recognized, including: children desks, portable desks and notebook desks, because they present a similar proposal to the one expected by the project. With this strategy, it was
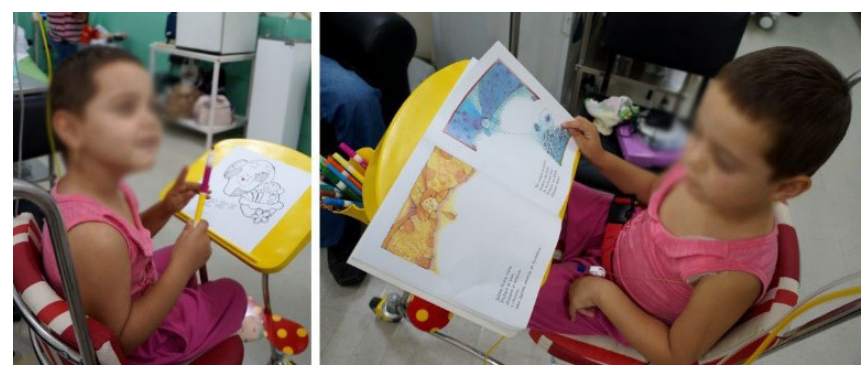

Figure 10. Patient of the HUSM Chemotherapy Ambulatory patients using the carrier. Source: Gonçalves (2014). possible to know existing solutions and to study possibilities for the product, recognizing systems, patterns, structures, forms, fittings, among other characteristics (Figure 12).

In addition to product analyses, knowing the final client is essential for any project; for this, it was decided to use panels that represented the user situation: who they are, where they live and how they live (Figure 13).

Even if this work was specifically aimed at CTCriaC patients, the possibility of a wider use was kept, that is, it is a proper product for the hospital medium, but that could also be used in other situations. For this reason, the target audience was defined as children and teenagers aged between 3 and 20, staying focused on the restrictions that the place of application requires. It was decided to exclude selected activities of patients with cancer and treat their characteristics as the ones of children and teenagers in general, since the product has the proposal of rescuing their day-by-day activities and take them into the hospital environment.

The concept phase was started choosing 3 words that included all the expectations with the product to be developed. They were: emotion, comfort and adaptation. Emotion was chosen with the intention that the product should have a positive relationship with the user, giving

\begin{tabular}{|c|c|c|c|c|}
\hline Phase & Problem & Comprehension & Configuration & Supervision \\
\hline Steps & Problem & $\begin{array}{l}\text { Researches and } \\
\text { Analyses }\end{array}$ & Concept and Design & Supervision \\
\hline Activities & $\begin{array}{l}\text { Define project scope; } \\
\text { formulate the problem. }\end{array}$ & $\begin{array}{l}\text { Research and analyze } \\
\text { the context. }\end{array}$ & $\begin{array}{l}\text { Reset the problem; } \\
\text { generate alternatives; } \\
\text { select alternatives; } \\
\text { Define and detail } \\
\text { the product. }\end{array}$ & Archive documents. \\
\hline & 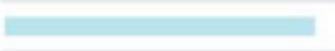 & 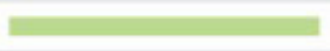 & 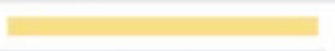 & \\
\hline Tools & $\begin{array}{l}\text { Set methodology; } \\
\text { Search on CTCriaC; } \\
\text { Carry out visits to the } \\
\text { hospital; Perform } \\
\text { photographic record; } \\
\text { Collect theoretical } \\
\text { references. }\end{array}$ & $\begin{array}{l}\text { Theoretical references; } \\
\text { synchronic research; } \\
\text { target public; panels } \\
\text { for analysis. }\end{array}$ & $\begin{array}{l}\text { List of requirements; } \\
\text { Brainstorm; Sketches; } \\
\text { Analysis of best } \\
\text { alternatives; } \\
\text { Requirements x } \\
\text { Alternative; Product } \\
\text { description; } \\
\text { Specifications; } \\
\text { Mockup/ Prototype. }\end{array}$ & \\
\hline
\end{tabular}

Figure 11. Methodology. Source: Rosa (2013). 


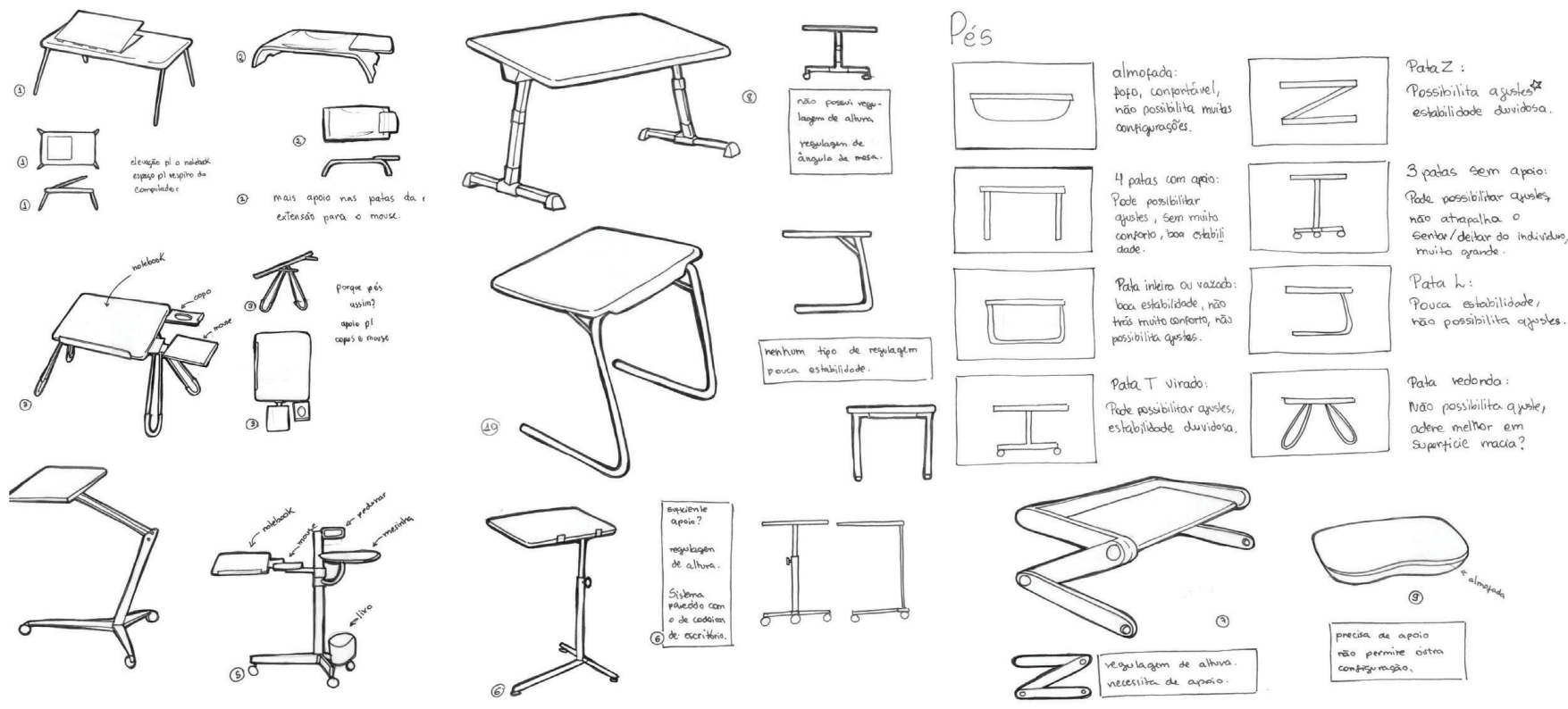

Figure 12. Analyses synthesis. Source: Rosa (2013).
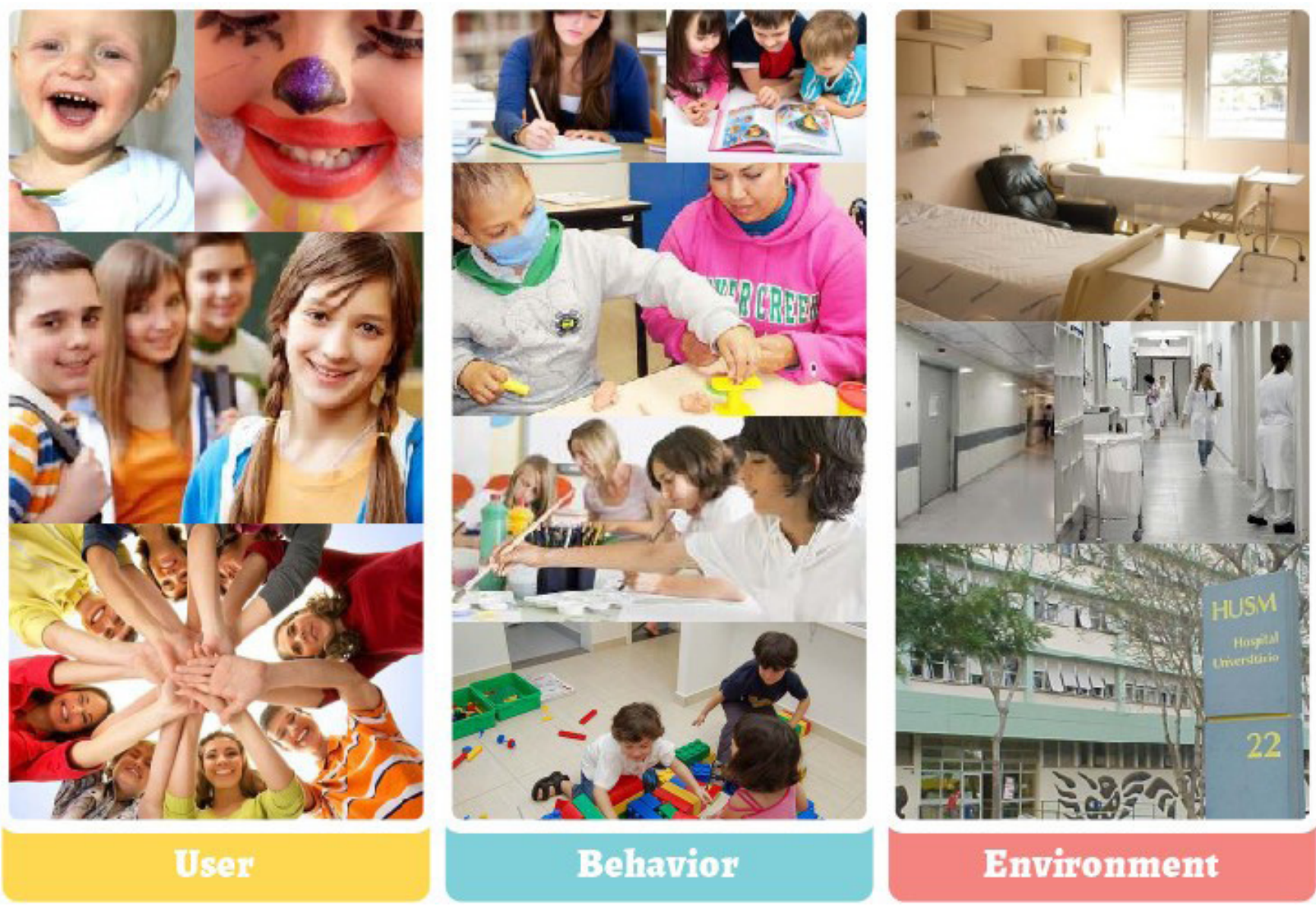

Figure 13. Panels referring to users. Source: Rosa (2013). 
good sensations and a friendly relationship with the place of stay. Comfort translates well-being, ease and coziness. It supplies the need to make users feel comfortable regardless of where they are. And last the adaptation, which corresponds to the need of the product to fit in a restricted environment and also to be configured in order to attend users' wishes.

According to the information collected and the elaboration of the product concept, the requirement definition and the problem redefinition may be concluded, and it is possible to start creating alternatives, now with a more focused and detailed vision of what was expected from the product project (Figures 14, 15). According to Bonsiepe (1984) requirements are used to "orient the project process in relation to the goals to be reached; and it is convenient to formulate each requirement separately, and use positive sentences, no denial. Thus, requirements were firstly listed starting from each item of the product.

Having listed each item's conditions, it is easier to visualize the product as a whole, and starting from these topics and adding items that were considered as needed, a summary of the product's requirements was developed, organizing what is expected from it, what it will not be able to be and how it should be (Figure 15).

Brainstorming was chosen as a tool to create alternatives, which consists in relating all ideas through sentences, words, drawings or chats. Prototypes were also used for tests, together with morphological boxes and drafts, going back to the ideas and modifying them as many times as necessary,

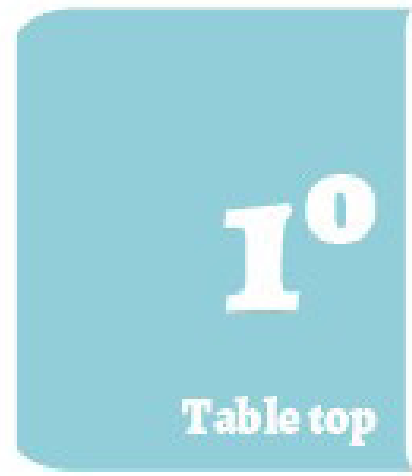

Provide support for different activities; Have support for laptops and books; Be independent of other furniture; Provide comfortable support; Easy sterilization; Rounded corners.

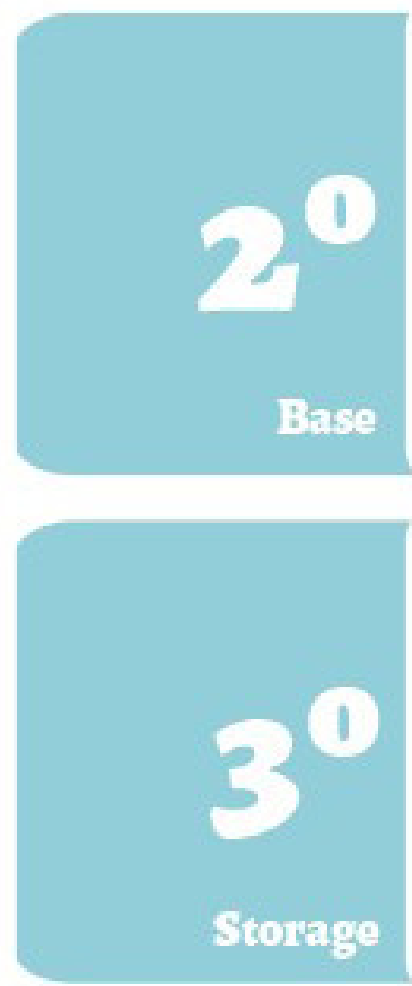

Stability;

Provide comfortable support;

Easy sterilization;

Rounded corners;

Easy handling.

\section{Adapt to the hospital routine;}

Space for storing objects;

Easy sterilization;

Rounded corners;

Easy handling.

Figure 14. Requirements per item. Source: Rosa (2013). 
until it was possible to identify a sketch that may adapt to requirements and production media (Figure 16).

Once the most appropriate alternative had been selected, it went through refinement and specifications; then, materials, colors, finishing and manufacture ways were chosen (Figure 17).

As a final product, a multiple activity support resembling a small desk was developed; it may be used to study, read, play, draw, eat, place notebooks, among others (Figures 18, 19).

Rods are retractable and easy to handle; the lid has a slot for illustrated activity sheets which is made by clips in the internal part to hold pages and it has a transparent canvas that users can scrap and easy to clean, discarding the use of paper, which is not very advisable inside hospitalization units (Figure 20).

Another great concern was the hospital flow, which has to be always working in order to better serve patients; therefore, it is not possible to have objects obstructing the way inside rooms, in case there is the need to move equipments or in case of doctors and other staff transit. In order not to disturb the hospital routine, in the back part of the product there are hooks, so that when not used, the desk may turn into a whiteboard to expose children drawings, hospital newsletters, messages, etc.

\section{How it should be ...}

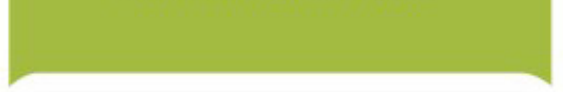

Suit the hospital routine;
Have rounded corners;
Enable sterilization;
Add value to the space;
Using existing technology
for production;
Easy handling;
Have several activities.

What is expected from it ...

Be available in different colors and patterns;

Low cost;

Multifunction;

Adaptable to different

environments.
What it will not be able to be ...

It can not present risk of injury; It can not be big; It can not facilitate the accumulation of bacteria.

Figure 15. Requirements. Source: Rosa (2013).

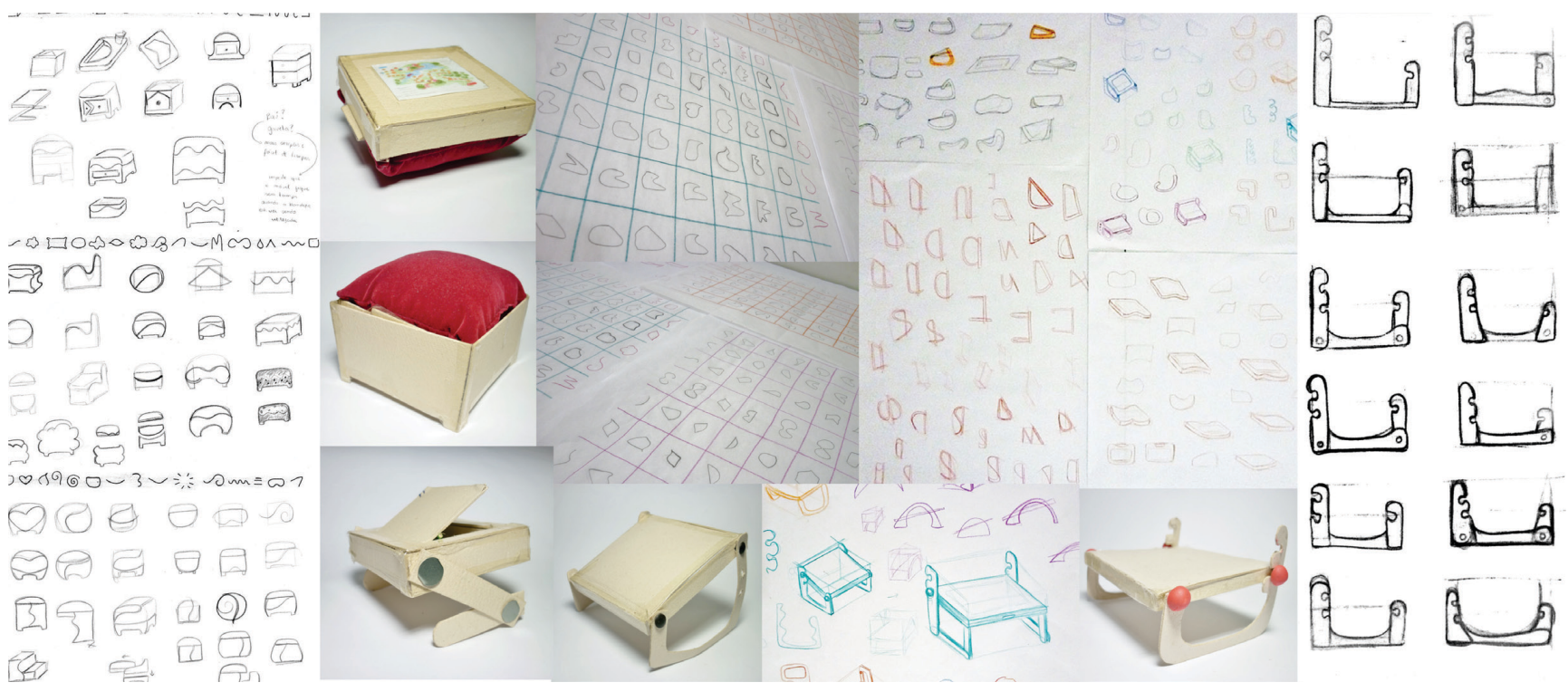

Figure 16. Alternative creation synthesis. Source: Rosa (2013). 

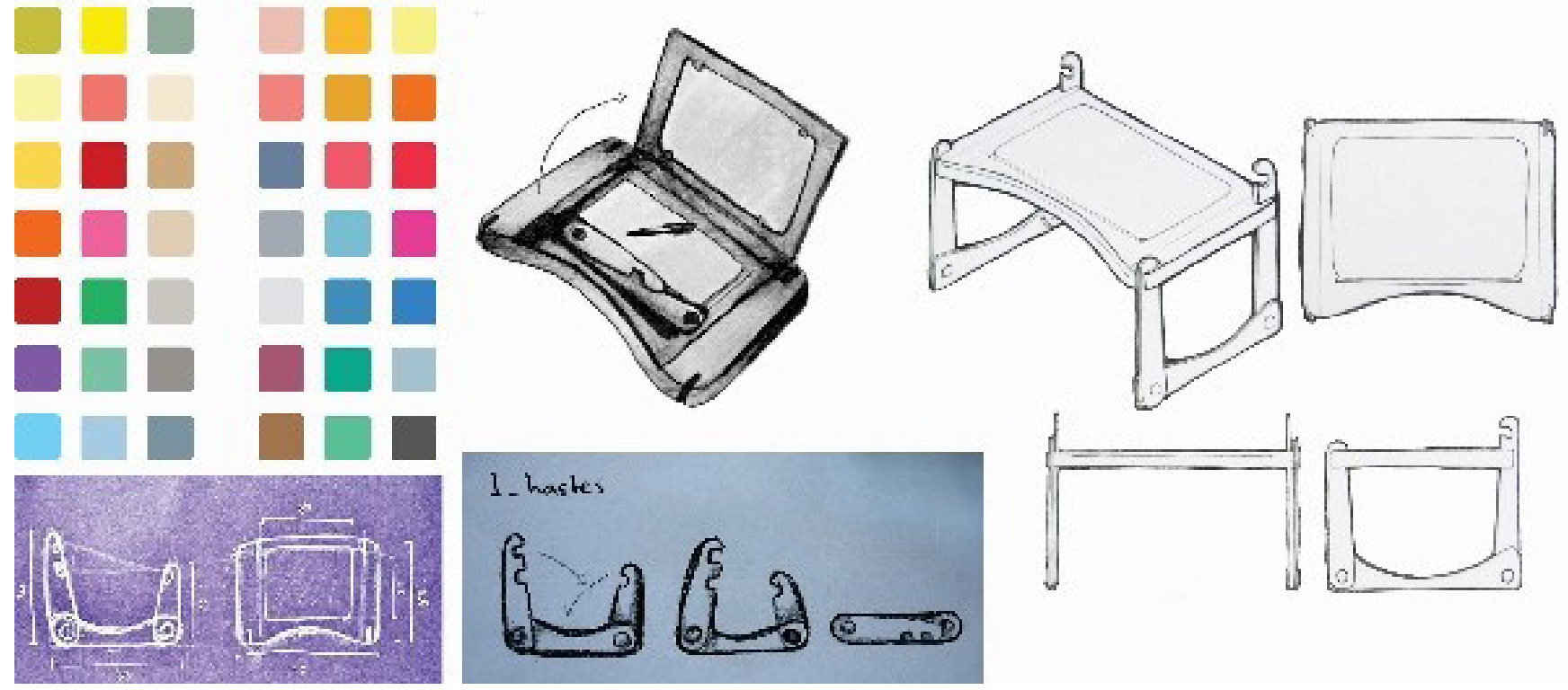

Figure 17. Synthesis of alternative and specification choice. Source: Rosa (2013).

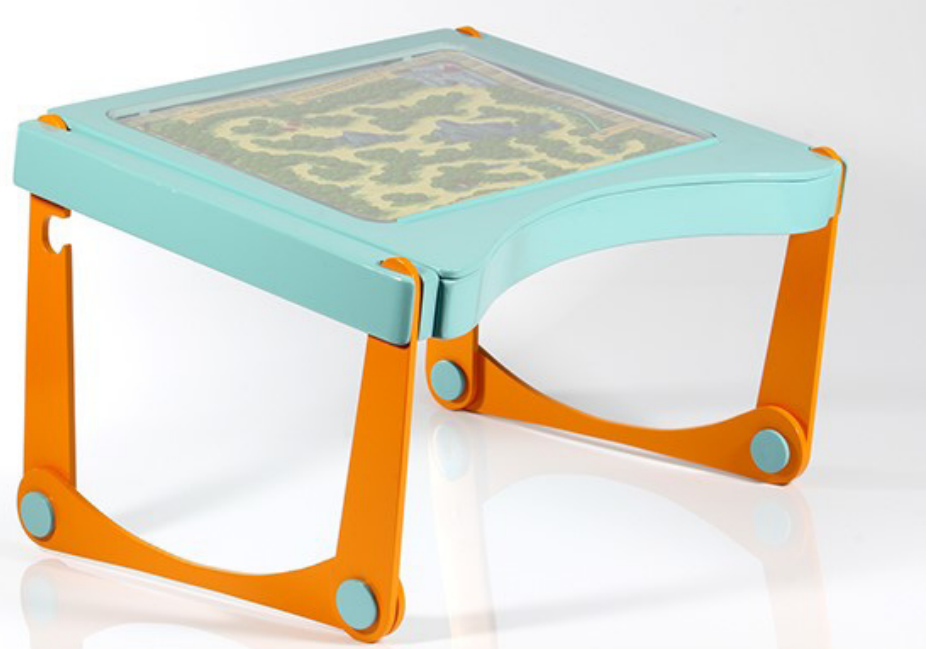

Figure 18. Final Product. Source: Rosa (2013).
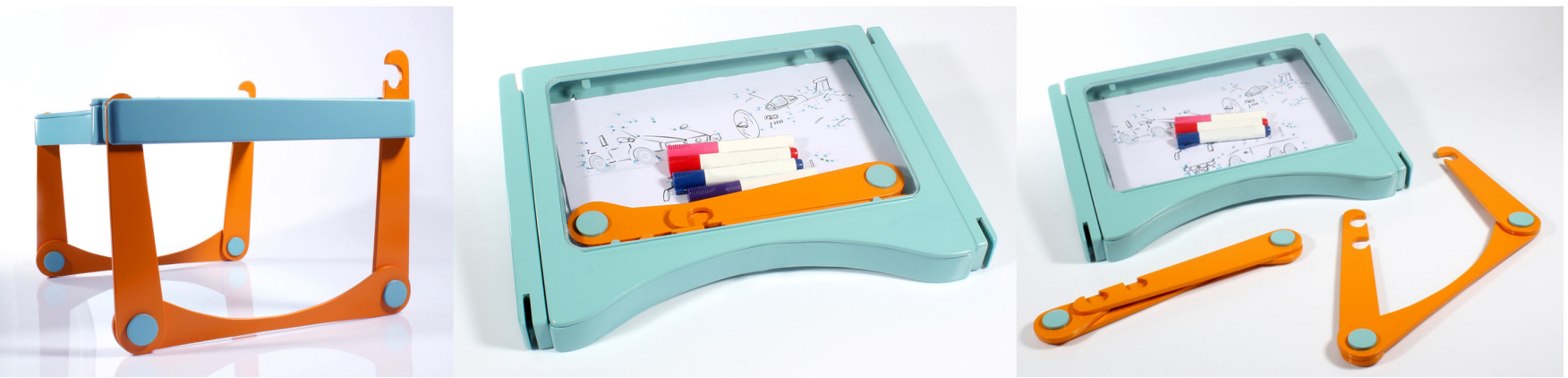

Figure 19. Final Product. Source: Rosa (2013). 


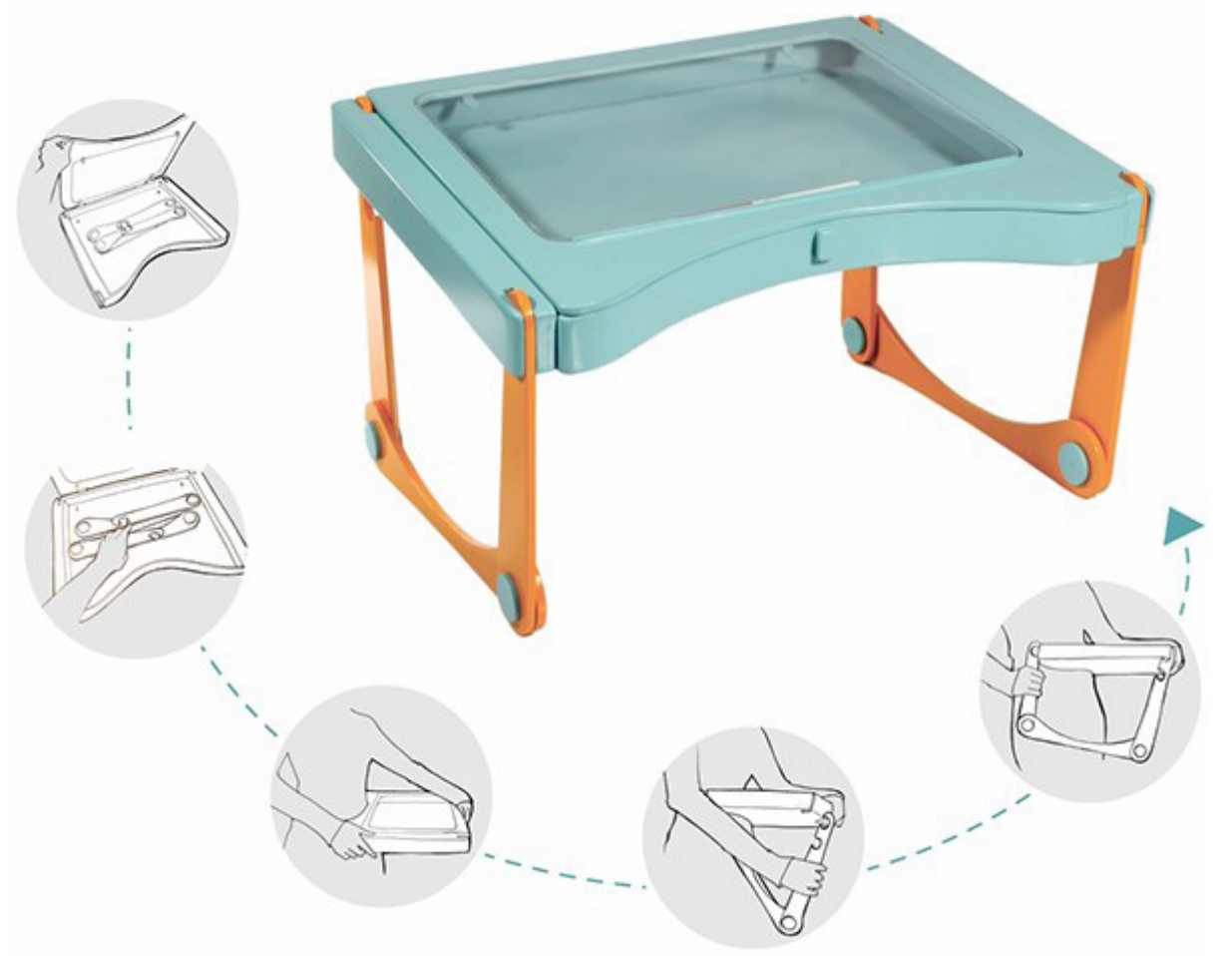

Figure 20. Product handling. Source: Rosa (2015).

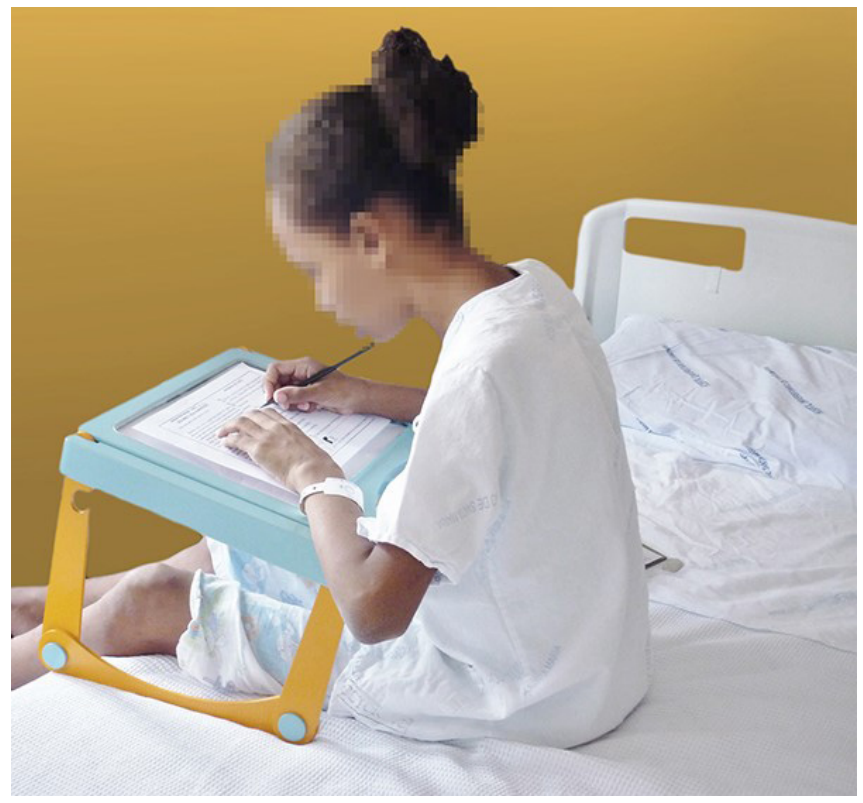

Figure 21. Patient using the product (10 years old). Source: Rosa (2015).

It also has the possibility to be stored because it may be disassembled, and in order to not occupy too much space, toys and rods can be stored inside it, avoiding problems and material loss. The possibility to be stored also helps in case the object needs to be transported.
After taking the product to the hospital, the received feedback was quite positive among children, teenagers, occupational therapists, doctors and nurses who were on site and could see the product working. When we arrived on site, one of the hospitalized children was doing her homework on a clipboard, with her back bent in an uncomfortable position that was not proper for the task. Children who are undergoing treatments tend to feel weak and the physical weariness caused by the lack of proper equipment damage them. Therefore, she was offered the desk to do her activities and her first statement was "That's better, now I can lean my hand..." (Figure 21).

A better posture was also noticed with the use of the desk and as well as these contributions, the product was judged as visually pleasant. The product was also tested on another older patient and on a child with the minimum age to use it (Figure 22).

With the prototype it is possible to confirm that the product presents in its configuration all the concepts that started creation: comfort, adaptation and emotion. The opportunity of testing the product with the target audience and in the place that it was designed for allowed project validation; thus, it was possible to check if the proposal was satisfactory and if the product acted in the desired way, obtaining a positive evaluation. Its shape and colors bring happier and childish characteristics to rooms, breaking hospital color patterns. The practicality 


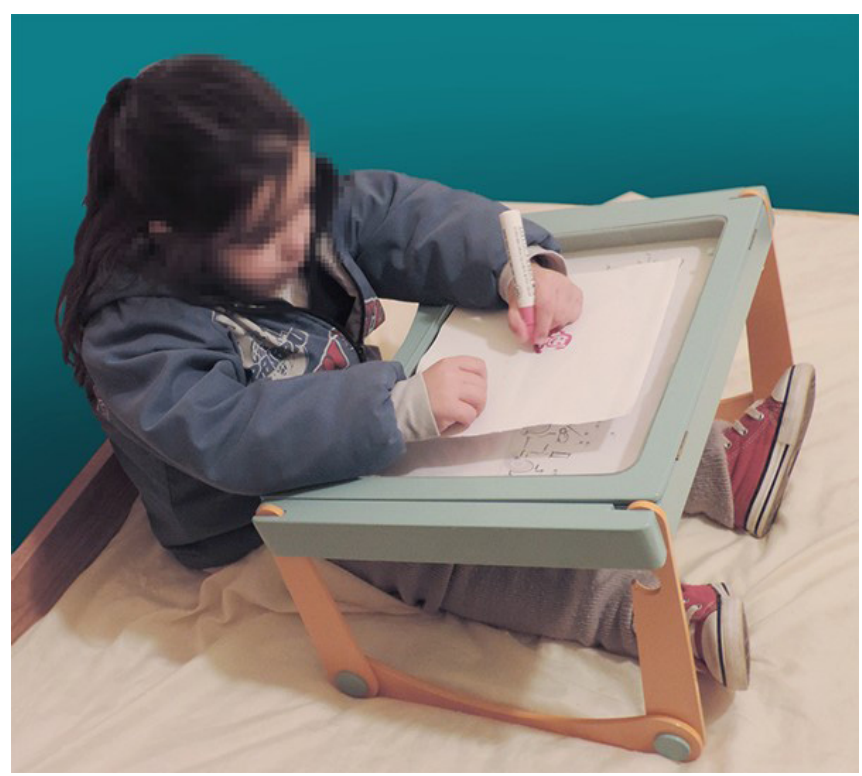

Figure 22. Child using the product. Source: Rosa (2015).

it presents brought more comfort to patients, being able to attend parents and healthcare professional as well, such as occupational therapists, who perform activities with hospitalized children and teenagers, and so far did not have a proper support. As well as attending its purpose, the desk presents potential to help inside the hospital and also in other environments, because it does not restrict its use and it adapts to different manners of use.

\section{Conclusion}

This was a challenging work, not only involving the designer's technical abilities but also the emotional ones, in order to have enough sensitivity to engage in the world of children, which, generally immersed in fantasy and dreams, makes it hard to understand how to face an illness that steals the interaction with family, friends, home, toys, and often, life.

During development, it was possible to understand the universe involving illnesses and the routines of the hospital medium, understanding its limits and cares and designing in a responsible way so that these characteristics are respected and thinking about treatments as a whole, involving medicines, environment, activities and relationships developed during this period.

As well as promoting the experience in the hospital environment, the contact with children under treatment and the way to face a serious disease such as cancer, this work allowed to observe feelings involving patients in these conditions. Emotions pervade life every moment; in the end, "[...] without fun and pleasure, joy and enthusiasm, and even anxiety and rage, fear and fury, our lives would be incomplete" (NORMAN, 2008, p. 28).
With this work, the goal of producing two products for entertainment and fun in the treatment environment was achieved.

One of the obtained results was a carrier that allows, as well as going around the hospital, performing recreational activities through a support clipboard whereas the child is undergoing medical treatments. Generally, moving around the hospital area is performed with the use of wheelchairs, which gives a sensation of inability, limitation, illness. In this case, recreational design transforms the simple act of moving in a game, transmitting happiness, adventure and discover. Therefore, this work helps oncologic treatment in a subjective way for children, because "[...] it is through playing that children may benefit from the available physical resources in that context to create a new situation" (MELLO et al., 1999, p.64).

Moreover, it enhanced the possibility of using it, not only in the Chemotherapy Ambulatory of the Hospital Universitário de Santa Maria, but in any treatment unit for children in hospitals, even allowing bedridden children to play through the serum/medicine support.

The multiple activity desk was also designed; it allows, through its formal resources, recreation and mobility so that patients, even the bedridden ones, may perform the most diverse activities and benefit from different fun moments during the hospitalization period. The project achieved the goal of being proper for the hospital environment and received good responses from the users, and even if the main audience were CTCriaC patients, the product does not have exclusive characteristics, without presenting contraindications to be used in other environments such as houses or schools. Despite the fact that needs were identified through the studied environments, there is nothing to prevent the carrier to be used in the CTCriaC, in the same way the desk may be used in the chemotherapy ambulatory.

Results obtained with this work were satisfactory, since both models could be configured so that they could be tested by users; this allowed demonstrating its effectiveness and functionality according to the proposal.

Interdisciplinarity was essential to develop this work. The contact with occupational therapy, nursing, architecture and other areas, helped a lot of knowledge exchange. It is important to remember that design is not alone searching for solutions, but it can join the most diverse areas, working to achieve improvements and obtain more significant results through the union of different competences and knowledge.

In conclusion, with the project implantation, we hope the effect will be as pleasant as possible, so that it makes hospitalization more fun and less painful for children that undergo treatments.

Moreover, there are different possibilities within the hospital environment for design to act; we hope that, in 
the future, more actions meant for this universe will be produced.

\section{References}

BAXTER, M. Projeto de produto: guia prático para o design de novos produtos. São Paulo: Blücher, 1998.

BEGNIS, G. J.; CARVALHO, A. M. Brincar em unidades de atendimento pediátrico: aplicações e perspectivas. Psicologia em estudo, v. 11, n. 1, p. 109-117, 2006. Available from: <http://www.scielo.br/pdf/pe/v11n1/ v11n1a13>. Access in: 23 May 2013.

BONSIEPE, G. Metodologia experimental/desenho industrial. Brasília: CNPq/Coordenação Editorial, 1984.

BORTOLOTE, G. S.; BRÊTAS, J. R. S. O ambiente estimulador ao desenvolvimento da criança hospitalizada. Rev. Escola de Enfermagem, São Paulo, 2008. Available in: $<$ http://www.scielo.br/pdf/reeusp/v42n3/v42n3a01.pdf $>$ Access in: 21 July 2013.

BROD, J. M.; ROMANO, F. V. Metodologia específica para educação projetual e ensino de Desenho Industrial. Santa Maria: UFSM, 2013. Notas de aula da disciplina Teoria e Metodologia do Desenho Industrial, Curso de Desenho Industrial.

GOMES, I. P.; COLLET, N.; REIS, P. E. D. Ambulatório de Quimioterapia: a experiência no Aquário Carioca. Texto Contexto Enfermagem, v. 20, n. 3, p. 585-591, 2011.

GOMES, L. A. V. N.; MEDEIROS, L. S. Ideias, ideais e ideações: para design/desenho industrial. Porto Alegre: Uniritter, 2010.

GONÇALVES, A. E. S. Design lúdico: carrinho para auxiliar o tratamento oncológico infantil. 2014. 147 f. Trabalho de Conclusão de Curso (Graduação)-Curso de Desenho Industrial Projeto de Produto, Universidade Federal de Santa Maria, Santa Maria, 2014.

GUIA INFANTIL. O câncer infantil. 2013. Available from: $<$ http://br.guiainfantil.com/cancer-infantil.html $>$. Access in: 01 July 2013.

INSTITUTO DESIDERATA. Como atuamos. 2013. Available from: $<$ http://www.desiderata.org.br/OncComoAtuamos $>$. Access in: 01 July 2013.

INSTITUTO NACIONALDE METROLOGIA, QUALIDADE E TECNOLOGIA - INMETRO. Brinquedos. Rio de Janeiro: INMETRO, 2013. Available from: <http://www. inmetro.gov.br/imprensa/releases/brinquedos.asp $>$. Access in: 01 July 2013.
INSTITUTO NACIONAL DO CÂNCER - INCA. Particularidades do câncer infantil. Rio de Janeiro: INCA, 2013. Available from: <http://www.inca.gov.br/ conteudo_view.asp?id=343>. Access in: 01 July 2013.

LESKO, J. Design industrial: guia de materiais e fabricação. São Paulo: Blücher, 2012.

LÖBACH, B. Design industrial: bases para a configuração dos produtos industriai. São Paulo: Blücher, 2001.

MARGOLIN, V. Design, the future and the human spirit. Design Issues, v. 23, n. 3, 2007. Available from: <http://www. mitpressjournals.org/doi/pdf/10.1162/desi.2007.23.3.4>. Access in: 03 June 2013.

MATTE, V. A. et al. Método flexível para a atividade projetual do design: uma proposta de jogo. In: CONGRESSO BRASILEIRO DE GESTÃO DE DESENVOLVIMENTO DE PRODUTOS, 9., 2013, Natal. Anais... Natal: CBGDP, 2013. p. 1-10.

MELLO, C. O. et al. Brincar no hospital: assunto para discutir e praticar. Psicologia: Teoria e Pesquisa, v. 15, n. 1, p. 65-74, 1999.

MENEZES, C. Design \& emoção. Revista ABC Design, v. 24, p. 28-29, 2008.

MOTTA, A. B.; ENUMO, S. R. F. Câncer Infantil: uma proposta de avaliação das estratégias de enfrentamento da hospitalização. Estudos de Psicologia, v. 21, n. 3, p. 193202, 2004. Available from: <http://www. oncopediatria. org.br/cancer-infantil-uma-proposta-de-avaliacao-dasestrategias-de>. Access in: 09 May 2013.

NORMAN, D. Design emocional: por que adoramos (ou detestamos) os objetos do dia-a-dia. Rio de Janeiro: Rocco, 2008.

PAZMINO, A. V. Uma reflexão sobre Design Social, Eco Design e Design Sustentável. In: SIMPÓSIO BRASILEIRO DE DESIGN SUSTENTÁVEL, 1., 2007, Curitiba. Anais... São Paulo: UFPR, 2007. p. 1-4.

ROSA, C. R. Design no ambiente hospitalar: mesa para múltiplas atividades. 2013. 120 f. Trabalho de Conclusão de Curso (Graduação)-Curso de Desenho Industrial Projeto de Produto, Universidade Federal de Santa Maria, Santa Maria, 2013.

ROSA, C. R. MIMO: table for multiple activities. Behance, 2015. Available from: <https://www.behance.net/ gallery/13765437/MIMO-Table-for-Multiple-Activities>. Access in: 09 May 2013. 